\title{
WEED ESTABLISHMENT IN THE SECOND YEAR AFTER HIGH PASTURE SOWING RATES
}

\author{
M.L. ARMSTRONG ${ }^{1}$, K.C. HARRINGTON ${ }^{2}$ and S.S. SEEFELDT ${ }^{3}$ \\ ${ }^{1}$ AgResearch Ltd, PO Box 60, Lincoln \\ ${ }^{2}$ Institute of Natural Resources, Massey University, PB 11222, Palmerston North \\ ${ }^{3}$ US Sheep Experiment Station, HC 62 Box 2101, Dubois, Idaho 83423, USA \\ Corresponding author: michelle.armstrong@agresearch.co.nz
}

\begin{abstract}
A field and an outdoor tray experiment were conducted to determine whether weed control benefits of high sowing rates of perennial ryegrass (Lolium perenne) continue into the second year after sowing. Seeds of Scotch thistle (Cirsium vulgare), nodding thistle (Carduus nutans) and hedge mustard (Sisymbrium officinale) were sown into perennial ryegrass swards that were established 12 months earlier at differing densities. Emerging weed seedlings were mapped at regular intervals to enable their fate to be followed. Weed emergence and survival did not decline with increased ryegrass sowing rates indicating that 12 months after sowing the competitive ability of pasture sown at low density towards weeds equalled that of pasture sown at high density.

Keywords: sowing rate, Lolium perenne L., weed control, pasture competition.
\end{abstract}

\section{INTRODUCTION}

Throughout the world there has been increasing interest in reducing the amount of pesticides applied in agricultural systems. This mainstream trend is influenced in part by the rapidly growing organics industry (Gendall et al. 1999). Herbicides tend to be the only pesticide applied widely to pastures (Holland \& Rahman 1999), and therefore any attempt to reduce chemical inputs in pastoral agriculture must address the issue of herbicide use. During pasture renovation herbicides can be applied both pre and post sowing of the pasture species in an attempt to reduce weed competition for the young pasture plants. To avoid or reduce the need for chemicals at this vulnerable stage, more competitive pasture may be achieved by increasing the sowing density of the grass species. Previous studies have investigated the concept of increasing pasture sowing rates in an attempt to both increase early pasture production and to out-compete weeds during pasture establishment (Cullen \& Meeklah 1959; Seefeldt \& Armstrong 2000). However, there is a lack of information regarding the ongoing benefits (if any) of this management strategy. Armstrong et al. (2001) found that high perennial ryegrass sowing had either no effect or a positive effect on ragwort (Senecio jacobaea) emergence in the second year after establishment. The current paper presents results from the same trial for Scotch thistle, nodding thistle and hedge mustard.

\section{Tray experiment}

\section{MATERIALS AND METHODS}

In September 1999, perennial ryegrass (cv. Bronsyn) was sown into polystyrene trays at rates of $0,5,10,20,40,80,160$ and $320 \mathrm{~kg}$ seed/ha. All trays were also sown with $5 \mathrm{~kg} / \mathrm{ha}$ of white clover (Trifolium repens) seed (50:50 mix of Sustain and Aran). The trays measured $540 \times 340 \times 80 \mathrm{~mm}$ deep and were filled with Horotiu silt loam soil (organic $\mathrm{C} 6.2 \%$, sand $58 \%$, clay $15 \%$ and silt $27 \%$ ). The trays were watered as required and fertilised with Long Ashton nutrient solution (Hewitt 1966). After 50 days in the 
glasshouse the trays were placed outside. The swards were trimmed monthly to a height of $30 \mathrm{~mm}$ using electric hand shears and all volunteer weeds were removed. Slug bait (Mesurol, $20 \mathrm{~g}$ methiocarb/kg at $10 \mathrm{~kg} / \mathrm{ha}$ ) was applied monthly.

On 18 May 2000, eight months after pasture establishment, seed of a single weed species was sown into each tray. The seeds were scattered evenly into a $200 \times 250 \mathrm{~mm}$ area at least $60 \mathrm{~mm}$ from the side of the tray (to reduce edge effect). Each tray received 125 seeds of Scotch thistle, 500 seeds of hedge mustard or 500 seeds of nodding thistle. In the same week pasture composition was assessed through counts of perennial ryegrass tillers and white clover growing points in a $5 \times 20 \mathrm{~cm}$ quadrat. At monthly intervals, immediately after trimming, all emerged weed seedlings were mapped to enable the fate of individuals to be followed. Scotch thistle seedlings were counted and removed on 31 August 2000. The other two species were counted and removed on 5 October 2000.

\section{Field experiment}

A field experiment was established at the Ruakura Research Centre on 14 April 1999. The site was ploughed and harrowed before seeding and rolled after seeding. The treatments were perennial ryegrass (cv. Bronsyn) sown at $0,5,10,20,40 \mathrm{or} 80 \mathrm{~kg}$ seed/ha. All plots were also sown with $5 \mathrm{~kg} / \mathrm{ha}$ of white clover seed (50:50 mix of cv. Sustain and Aran). Plots were $3 \times 7 \mathrm{~m}$ and the treatments were arranged in a randomised complete block design, with four replicates. Emerging volunteer plants, both weeds and unsown grass species, were left in the plots to mimic a realistic pasture situation. The plots were grazed every 5-6 weeks by young cattle.

On 18 April 2000, 12 months after sowing, four sub-plots measuring $200 \times 250 \mathrm{~mm}$ were located at random in each plot, permanently marked, and sown with either 250 Scotch thistle, 500 hedge mustard or 500 nodding thistle seeds. The seed was evenly scattered in the plot by hand. In the same week ten cores (each $50 \mathrm{~mm}$ diameter) were taken at random from each plot, and for each core, perennial ryegrass tillers, white clover growing points, weed surface area and tillers of volunteer grasses were counted. Immediately before and after every grazing the position of each individual sown weed seedling was mapped to enable the fate of individuals to be followed. The experiment continued for seven months (until 22 November 2000) by which time most of the emerged weed seedlings had disappeared.

Analyses of the emergence results were conducted by ANOVA. Mortality data was analysed using a generalised linear model of the number of deaths compared with the number of plants emerged, using a binomial error distribution and the natural logit (log odds) "link" function (Genstat 5 Release three), with the rate of sown ryegrass fitted as an independent variable.

\section{RESULTS AND DISCUSSION}

In both the tray and field experiments, emergence of the three weed species (Scotch thistle, hedge mustard and nodding thistle) was not influenced by the original perennial ryegrass sowing rate (Tables $1 \& 2$ ). Similar emergence results were found with ragwort where seedling emergence in the second year after pasture establishment was either unaffected or slightly increased by an increase in ryegrass sowing rate (Armstrong et al. 2001). All treatments resulted in very low numbers of hedge mustard seedlings emerging in the field experiment, so differences between treatments could not be ascertained.

Germination tests conducted in Petri dishes indicated that the hedge mustard seed was highly germinable (70\%). Therefore the low emergence of hedge mustard may be attributed to competition from the established pasture although other factors may also be involved, such as invertebrate seed predation or fungal infection (Tables $1 \& 2$ ). Although nodding thistle emergence was also low in both the field and tray experiments, germination tests had indicated that the seed used had a low germination percentage $(17 \%)$ and therefore much of the low germination could be attributed to poor quality seed rather than the treatments. In other experiments pasture competition has been shown to severely inhibit nodding thistle establishment (Wardle et al. 1995). 
TABLE 1: Sward composition and emergence of sown weed seeds in tray experiment. Figures in round brackets indicate square root transformation. Figures in square brackets indicate number of replicates.

\begin{tabular}{|c|c|c|c|c|c|}
\hline \multirow{2}{*}{$\begin{array}{c}\text { Original } \\
\text { sowing rate } \\
\text { (kg ryegrass } \\
\text { seed/ha) }\end{array}$} & \multicolumn{2}{|c|}{ Mean sward composition ${ }^{1}$} & \multicolumn{3}{|c|}{ Weed emergence $^{2}$} \\
\hline & $\begin{array}{c}\text { Ryegrass } \\
\left(\text { tillers } / \mathrm{m}^{2}\right)\end{array}$ & $\begin{array}{c}\text { White clover } \\
\text { (growing } \\
\text { points } / \mathrm{m}^{2} \text { ) }\end{array}$ & $\begin{array}{l}\text { Scotch } \\
\text { thistle } \\
(\%)\end{array}$ & $\begin{array}{l}\text { Hedge } \\
\text { mustard } \\
(\%)\end{array}$ & $\begin{array}{c}\text { Nodding } \\
\text { thistle } \\
(\%)\end{array}$ \\
\hline 0 & 0 & 3556 & $43.7 \quad[3]$ & $0.9[3]$ & $1.1(1.0) \quad[3]$ \\
\hline 5 & 4391 & 1773 & 38.4 [3] & $0.5[4]$ & $2.6(1.6) \quad[4]$ \\
\hline 10 & 4730 & 1330 & 30.7 & 0.7 [4] & $1.1(1.1)$ [3] \\
\hline 20 & 6208 & 1350 & $33.6[4]$ & $0.2[4]$ & $1.2(1.1)$ \\
\hline 40 & 7209 & 964 & 27.5 & 0.2 & $1.4(1.2)$ [4] \\
\hline 80 & 8617 & 850 & $36.6[4]$ & 0.3 [4] & $1.9(1.3)$ [4] \\
\hline 160 & 9400 & 1033 & 29.6 & $0.5[4]$ & 1.9 (1.4) [4] \\
\hline 320 & 13083 & 417 & 28.0 & 0.5 & $2.6(1.6) \quad[4]$ \\
\hline & 1676 & & 13.5 & 0.6 & $(0.5)$ \\
\hline Linear trend & $\mathrm{P}<0.001$ & $\mathrm{P}<0.001$ & $\mathrm{~ns}$ & ns & $\mathrm{ns}$ \\
\hline
\end{tabular}

${ }^{1}$ Assessed 18 May 2000. ${ }^{2}$ Assessed between 18 May 2000 and 5 October 2000. ${ }^{3}$ Sown 7 September 1999.

TABLE 2: Sward composition and emergence of sown weed seeds in field experiment. Figures in brackets indicate square root transformation.

\begin{tabular}{|c|c|c|c|c|c|c|c|}
\hline \multirow[b]{2}{*}{$\begin{array}{l}\text { Original } \\
\text { sowing } \\
\text { rate }(\mathrm{kg} \\
\text { ryegrass } \\
\text { seed } / \mathrm{ha})^{3}\end{array}$} & \multicolumn{4}{|c|}{ Sward composition $^{1}$} & \multicolumn{3}{|c|}{ Weed emergence $^{2}$} \\
\hline & $\begin{array}{c}\text { Ryegrass } \\
\left(\text { tillers } / \mathrm{m}^{2}\right)\end{array}$ & $\begin{array}{c}\text { White } \\
\text { clover } \\
\text { (growing } \\
\text { points } / \mathrm{m}^{2} \text { ) }\end{array}$ & $\begin{array}{l}\text { Other } \\
\text { grasses } \\
\text { (tillers/ } \\
\mathrm{m}^{2} \text { ) }\end{array}$ & $\begin{array}{l}\text { Weeds } \\
(\% \\
\text { surface } \\
\text { area) }\end{array}$ & $\begin{array}{c}\text { Scotch } \\
\text { thistle } \\
(\%)\end{array}$ & $\begin{array}{c}\text { Hedge } \\
\text { mustard } \\
(\%)\end{array}$ & $\begin{array}{c}\text { Nodding } \\
\text { thistle } \\
(\%)\end{array}$ \\
\hline 0 & $\begin{array}{r}524 \\
(22.9)\end{array}$ & $\begin{array}{r}2894 \\
(53.8)\end{array}$ & $\begin{array}{r}1376 \\
(37.1)\end{array}$ & 0.38 & 24.0 & 0 & 0.35 \\
\hline 5 & $\begin{array}{l}676 \\
(26)\end{array}$ & $\begin{array}{r}2391 \\
(48.9)\end{array}$ & $\begin{array}{r}437 \\
(20.9)\end{array}$ & 0.49 & 22.6 & 0 & 0.05 \\
\hline 10 & $\begin{array}{r}1253 \\
(35.4)\end{array}$ & $\begin{array}{r}2981 \\
(54.6)\end{array}$ & $\begin{array}{r}515 \\
(22.7)\end{array}$ & 0.06 & 22.3 & 0.15 & 0.50 \\
\hline 20 & $\begin{array}{r}2294 \\
(47.9)\end{array}$ & $\begin{array}{r}3260 \\
(57.1)\end{array}$ & $\begin{array}{r}132 \\
(11.5)\end{array}$ & 0.04 & 26.0 & 0.25 & 0.85 \\
\hline 40 & $\begin{array}{r}2144 \\
(46.3)\end{array}$ & $\begin{array}{r}1648 \\
(40.6)\end{array}$ & $\begin{array}{r}384 \\
(19.6)\end{array}$ & 0.03 & 22.1 & 0.30 & 1.45 \\
\hline 80 & $\begin{array}{r}3721 \\
(61)\end{array}$ & $\begin{array}{r}864 \\
(29.4)\end{array}$ & $\begin{array}{r}3 \\
(1.8)\end{array}$ & 0.06 & 22.0 & 0.05 & 0.50 \\
\hline $\operatorname{LSD}(\mathrm{P}=0$. & 15) (22.0) & $(16.3)$ & $(19.1)$ & \# & 14.3 & \# & 0.73 \\
\hline Linear tren & d $\quad \mathrm{P}<0.01$ & $\mathrm{P}<0.01$ & $\mathrm{P}<0.01$ & \# & ns & \# & $\mathrm{ns}$ \\
\hline
\end{tabular}

${ }^{1}$ Assessed 18 April 2000. ${ }^{2}$ Assessed between 18 April 2000 and 22 November 2000. ${ }^{3}$ Sown 14 April 2000 . \# Not analysed due to zeros. 
Mortality of weed seedlings in both the field and tray experiments was either unaffected or decreased with an increase in the previous year's perennial ryegrass sowing rate (Table 3). There was a significant trend in the field for Scotch thistle mortality to decrease as sowing rate increased. This may have been due to the dense grass canopy providing the weed seedlings with some physical protection from the grazing animals. In the field, all of the hedge mustard seedlings that emerged died, while only one nodding thistle seedling survived. The mean percent mortality of Scotch thistle in the tray experiment never exceeded $5 \%$ of the seedlings that emerged. Hedge mustard and nodding thistle results indicated occasional high mortality in the trays, however, due to the low emergence values of these two species the actual number of seedlings dying was low also.

The significantly higher mortality that occurred in the field experiment when compared to the trays could be attributed to reduced inter-specific competition in the trays or to physical damage by grazing animals and burial by worm casts in the field. The periodic addition of water and nutrients and the regular and uniform trimming in the trays may have reduced the chances of nutrients, water and light becoming limiting. The effect of competition in the trays was also reduced by the shorter time frame of the tray experiment than the field experiment. Young weed seedlings in the field are easily killed through treading and burial by dung. We also observed mortality in the field due to worm casts covering newly germinated weeds at the cotyledon stage.

High grass sowing rates have been shown to suppress weed growth in the first year after sowing due to the increased competitive pressure exerted on the weed population by dense swards of perennial ryegrass (Cullen \& Meeklah 1959; Seefeldt \& Armstrong 2000). In our field experiment fewer unsown grasses were present in higher ryegrass sowing rate plots, and there was also some evidence of fewer weeds at higher sowing rates (Table 2). However these experiments indicated that the effect of increased weed suppression from high perennial ryegrass sowing rates was lost after the first year. This may have been due to infill by white clover, volunteer weeds and grasses in the low sowing rate plots and self-thinning in the high perennial ryegrass sowing rate plots resulting in similar competitive pressure in all treatments. Higher sowing rates did allow less weed invasion in the first year, and therefore presumably higher production from these swards, as well as a lower amount of weed seed returned to the seedbank to reduce future weed populations. Disadvantages from high ryegrass seeding rates are increased seed costs and the decrease in white clover establishment (Table 1) caused by the strong perennial ryegrass competition (Armstrong 2001).

TABLE 3: Percent mortality of emerged weeds during field and tray experiments ${ }^{1}$.

\begin{tabular}{|c|c|c|c|c|c|c|}
\hline \multirow{2}{*}{$\begin{array}{l}\text { Sowing rate } \\
\text { (kg seed/ha) }\end{array}$} & \multicolumn{2}{|c|}{ Scotch thistle } & \multicolumn{2}{|c|}{ Hedge mustard } & \multicolumn{2}{|c|}{ Nodding thistle } \\
\hline & Field & Tray & Field & Tray & Field & Tray \\
\hline 0 & $100^{1}$ & 4.2 & 100 & 19.4 & 100 & 16.7 \\
\hline 5 & 99 & 2.7 & 100 & 0.0 & 100 & 9.9 \\
\hline 10 & 99 & 2.6 & 100 & 25.0 & 100 & 0.0 \\
\hline 20 & 98 & 0.0 & 100 & 0.0 & 100 & 4.5 \\
\hline 40 & 92 & 0.9 & 100 & 0.0 & 97 & 0.0 \\
\hline 80 & 89 & 5.5 & 100 & 0.0 & 100 & 4.2 \\
\hline 160 & - & 2.2 & - & 0.5 & - & 3.7 \\
\hline 320 & - & 2.3 & - & 0.3 & - & 6.3 \\
\hline Significance & $\mathrm{P}<0.001$ & $\mathrm{~ns}$ & - & $\mathrm{ns}$ & - & ns \\
\hline
\end{tabular}

${ }^{1}$ Percent mortality is the total number of plants that emerged minus the number of plants alive at the end, expressed as a percentage of the total number of weeds that emerged. 


\section{CONCLUSION}

One year after the pasture was sown there appears to be no advantages in higher perennial ryegrass sowing rates with respect to lower subsequent weed invasion. Emergence of the three weed species tested in these experiments was not affected by the perennial ryegrass sowing rate. Weed mortality rates did not appear to be related to the original sowing rates, although there was a possibility that the dense swards of ryegrass in the higher sowing rates provided some physical protection for the emerging seedlings of Scotch thistle. Therefore, the majority of the benefits of higher pasture sowing rates with respect to reducing weed invasion occur in the first year after sowing, where higher densities of perennial ryegrass can out-compete many slower growing or more prostrate weeds.

\section{ACKNOWLEDGEMENTS}

Funding for the project was provided by the New Zealand Foundation for Research, Science and Technology. The authors would like to thank Dave Saville for help with the statistical analysis.

\section{REFERENCES}

Armstrong, M.L. 2001: The effect of perennial ryegrass (Lolium perenne) sowing rates on weed establishment, after one year. Masters thesis, Massey University, Palmerston North, New Zealand.

Armstrong, M.L.; Seefeldt, S.S.; Harrington, K.C. 2001: Effect of perennial ryegrass density on ragwort emergence. N.Z Plant Prot. 54: 111-115.

Cullen, N.A.; Meeklah, F.A.H. 1959: Seeding rates and weedkillers in pasture weed control. Proc. $36^{\text {th }}$ N.Z. Weed and Pest Control Conf.:54-58.

Gendall, P.; Betteridge, K.; Bailey, W. 1999: Japan market for organics. Commercial Grower:24-25.

Hewitt, E.J. 1966: Sand and water culture methods used in the study of plant nutrition. Commonwealth Bureau of Horticultural and Plantation Crops Technical Communication No. 22.

Holland, P.T.; Rahman, A. 1999: Review of trends in agricultural pesticide use in New Zealand. MAF Policy Technical Paper 99/11. Ministry of Agriculture and Forestry, Wellington. $53 \mathrm{p}$.

Seefeldt, S.S.; Armstrong, M.L. 2000: Impact of perennial ryegrass seeding densities on weed emergence, growth and development. N.Z. Plant Prot. 53: 38-43.

Wardle, D.A.; Nicholson, K.S.; Ahmed, M.; Rahman, A. 1995: Influence of pasture forage species on seedling emergence, growth and development of Carduus nutans. J. Appl. Ecol. 32: 225-233. 